\title{
MONKS IN KAFTÂNS. BOSNIAN FRANCISCANS, ROBES OF HONOUR, AND OTTOMAN SUMPTUARY LAWS
}

\author{
Vjeran Kursar
}

Faculty of Humanities and Social Sciences, University of Zagreb

\section{ABSTRACT}

\begin{abstract}
In the Ottoman Empire, bestowing ceremonial robe of honour (kaftân or hil'at) represented acceptance into state service or promotion. This Ottoman tradition indicated both a sign of loyalty and favour as well as an expression of a hierarchical relationship between a giver and a receiver. Kaftâns and hil'ats were bestowed on state officials and religious dignitaries, as well as, occasionally, on foreign diplomats, vassals, and other foreign dignitaries. Several examples of bestowing of robe of honour on the Franciscan leaders indicate that they were, at least occasionally, officially treated and recognized as state servants. This was a significant exception to sharia-based sumptuary laws, which ban wearing of luxury and Muslim-style clothing to non-Muslims.
\end{abstract}

According to the Franciscan tradition, at the time of the conquest of Bosnia in 1463, the head of the Bosnian Franciscans, Fr. Andeo Zvizdović (d. 1498), was summoned in front of Sultan Mehmed II (r. 1444-1446, 1451-1481), in order to help the Ottoman conqueror pacify the land, establish a modus vivendi with the local Catholic population, and prevent further migrations outside the Ottoman borders. During the meeting, the sultan issued the monk an edict called 'abdnâme, which secured the rights of the Franciscans and their churches. Later generations understood 'ahdnâme as the founding document of Catholicism in Ottoman Bosnia and labelled it pactum regium. Although the Franciscan tradition tends to exaggerate its importance, and sometimes even compares it to Magna charta libertatis, while some scholars question its authenticity, 'ahdnâme was widely used as one of the basic documents in various official procedures, and it was recognized as authentic by the authorities. Therefore, in addition to the original kept in the Franciscan Monastery of Holy Spirit in Fojnica, almost every monastery in Bosnia possessed one or more copies of 'ahdnâme, including Fojnica, too. ${ }^{1}$ Despite vivid criticism

\footnotetext{
Josip Matasović, "Fojnička regesta," Spomenik Srpske kraljevske akademije 67, drugi razred 53, (1930): 62, 89-95; [Hazim Šabanović], "Turski dokumetni u Bosni iz druge polovine XV stoljeća," Istorisko-pravni zbornik 2 (1949): 207-208; Vančo Boškov, "Pitanje autentičnosti Fojničke ahd-name Mehmeda II iz 1463. godine," Godišnjak Društva istoričara BiH 28-30 (19771979): 87-105; Dominik Mandić, "Autentičnost Ahd-name Mehmeda II B.H. franjevcima," Radovi Hrvatskog Povijesnog Instituta u Rimu, 3-4 (1971): 61-90; Srećko M. Džaja, "Fojnička ahdnama u zrcalu paleografije, pravne povijesti i politike," Bosna Franciscana 17, no. 31 (2009): 103-128; Julijan Jelenić, Kultura i bosanski franjevci, vol. 1 (Sarajevo, 1912; reprint: Sarajevo: Svjetlost 1990), 140; Srećko M. Džaja, Konfesionalnost i nacionalnost Bosne i Hercegovine. Predemancipacijski period 1463-1804, (Sarajevo: Svjetlost, 1990), 153-155.
} 
and polemics concerning the authenticity of the document, modern scholarship eventually accepted the authenticity of its content, while the original document, it is assumed, might have been lost, and recreated later. ${ }^{2}$ Nevertheless, a partial authenticity of 'ahdnâme was confirmed by hard science in radiocarbon (Carbon 14) dating of its paper conducted in Institute "Ruđer Bošković" in Zagreb in May 2013. The lower part of the document, containing the main text, was dated in the period (the calibrated age span) 1430-1465 with probability $95.4 \%$, while the glued paper of the upper part of the document was dated $1665-1808$ with probability $73.8 \%{ }^{3}$ Thus, it seems that moderate criticism of 'ahdnâme of some authors, above all Vančo Boškov, was partly justified.

Another insignia item that testifies to the encounter between the sultan and the monk, according to the tradition, is an Ottoman ceremonial robe of honour, kaftân or hil'at, still preserved in the museum of the Monastery of Fojnica, nowadays in a somewhat different shape of a cloak. ${ }^{4}$ From the official point of view, this garment further implicated newly established relation between the state and the head of the Franciscan order in Bosnia, as bestowing of robes of honour symbolized acceptance into state service or promotion. ${ }^{5}$ Even though some highly critical authors doubt the historicity of the encounter because of the lack of contemporary sources, the existence of 'ahdname testifies its high probability, as does the appearance of Zvizdović in a contemporary edict (buyuruldu) issued by the governor of Bosnia, Sancakbegi İskender Pasha, in 1486. The document written in Bosnian Cyrillic script (bosanciica) addresses Zvizdović as the Bosnian Franciscan custodian and respectable monk, and grants him the right to travel freely inside and outside the Ottoman borders. In addition, it mentions his brothers - knezes (Croatian, "chief, headman") Domša and Milutin as the sultan's faithful servants. ${ }^{6}$ Franciscan chronicles, however, mention Zvizdović relatively late in the seventeenth and eighteenth centuries. Oral folk tradition, nevertheless, narrates in detail that after

Boškov, "Pitanje autentičnosti," 87-105. Recently on the basis of fermân of Sultan Bayazid II (r. 1481-1512) that confirmed 'ahdâme of Mehmed II in 1483, Michael Ursinus suggested that the original 'adhnâme was lost around 1483; see Michael Ursinus, "Ferman sultana Bajazida II. iz 1483. i fojnička ahdnama (izdana u Milodražu)," Bosna franciscana 27, no. 51 (2019): 9-26.

3 Nada Horvatinčić, Andreja Sironić, Jadranka Barešić and Igor Kozjak, "Radiocarbon dating of Ahdname, Mantel, and Armorial from the Fojnica Franciscan Monastery, Bosnia and Herzegovina," Radiocarbon 59, no. 5 (2017), 1366-1367.

4 Matasović, "Fojnička regesta," 89-91; and Boškov, "Pitanje autentičnosti," 92. On kaftân, see T. Majda, "Libās. IV - Turkey," Encyclopaedia of Islam, new edition, Vol. 5 (Leiden: Brill, 1986), 750752, and Mehmed Zeki Pakalın, Osmanlı Tarih Deyimleri, vol. 2 (Istanbul: Millî Eğitim Basımevi, 1971), 134 ("kaftan").

5 Pakalın, Osmanl Tarih Deyimleri, Vol. 2, 134 ("Kaftan giydirmek”); Amanda Phillips, "Ottoman Hil'at: Between Commodity and Charisma," in Frontiers of the Ottoman Imagination. Studies in Honour of Rhoads Murphey, ed. Marios Hadjianastasis (Leiden, Boston: Brill, 2015), 111-138.

6 Archive of the Franciscan Monastery of Holy Spirit, Fojnica, Bosnia and Herzegovina (henceforth: AF). Acta turcica. Rasuto. Bujruntija Skender-paše iz 1486. 
'abdnâme was handed to him, Zvizdović was donned by the sultan "with a ceremonial cloak covered with little stars, which was reflecting his surname [Croatian Zvizda/Zvijezda, "star"]." While Matasović might have been right in dismissing the story as legendary and trivial, ${ }^{8}$ it has to be mentioned that the case of bestowing ceremonial robe of honour to the head of the Bosnian Franciscans would not have been an exceptional case, but fitting into a pattern of promoting individuals in official status, entering state service, or paying special recognition, as in the cases of state officials, foreign ambassadors, vassal princess, and top ecclesiastics. Well-known examples from the Balkans and surrounding areas are donning kaftâns onto the Ragusan diplomats upon their arrival to Istanbul, ${ }^{9}$ the princes and senators of Transylvania, Moldavian voivodes, the khans of the Crimea (since the time of Süleymân I ("the Magnificent," r. 1520-66)), ${ }^{10}$ and the Orthodox Christian patriarchs of Constantinople. ${ }^{11}$ Ottoman tradition of bestowing kaftân or hil'at represents a continuation of the practice of earlier Muslim states introduced by the Abbasid caliphate. It indicated both a sign of loyalty and favour as well as an expression of a hierarchical relationship between the giver and the receiver. ${ }^{12}$

Robe of honour, sometimes mentioned under a more modest term kisve (Ott. garment, costume), was presented to converts to Islam as well. In this case, donning a new costume represented a visual symbol of the entrance into a new community of faithful. ${ }^{13}$ According to Stephan Gerlach, the assistant and clergyman of the ambassador of the Holy Roman Empire David Ungnad von Sonnegg, two grooms of the ambassador, named Georg and Benedict, converted to Islam at the Imperial Divan in 1576. During the ceremony, they raised their fingers, pronounced the shahada (the Islamic testimony of faith), threw their hats on the ground and put turbans on their heads. They were given Muslim names; Georg became Mustafa,

[Antun Knežević], Bosanski prijatelj, Vol. 4 (Zagreb: Knjižara Svetozara Galca, 1870), 142; Vlajko Palavestra, "Historijska narodna predanja i toponomastika u Fojnici i okolini," Glasnik Zemaljskog muzeja u Sarajevu (Etnologija) n.s. 27/28 (1974): 112. On Zvizdović see: Miro Vrgoč, "Fra Anđeo Zvizdović (1420./?/-1498.)," in Duhovni stupovi Bosne Srebrene (Sarajevo - Zagreb: Svjetlo riječi, 2007), 7-40.

8 Matasović, “Fojnička regesta," 91.

9 Vesna Miović, Dubrovačka diplomacija u Istambulu (Zagreb and Dubrovnik: Hrvatska akademija znanosti i umjetnosti, Zavod za povijesne znanosti u Dubrovniku, 2003), 71, 77.

10 János B. Szabó and Péter Erdősi, "Ceremonies Marking the Transfer of Power in the Principality of Transylvania in East European Context," Majestas 11 (2003): 111-160.

11 Nikolaos Vryzidis, "Textiles and Ceremonial of the Greek Orthodox Church under the Ottomans: New Evidence on Hil'ats, Kaftans, Covers, and Hangings," Journal of the Ottoman and Turkish Studies Association 6, no. 1 (2019): 61.

12 Phillips, “Ottoman Hil'at," 129.

13 Phillips, "Ottoman Hil'at," 119-121; Marc David Baer, Honored by the Glory of Islam: Conversion and Conquest in Ottoman Empire (Oxford: Oxford University Press, 2008), 190, 198-199; Anton Minkov, Conversion to Islam in the Balkans: Kisve Bahast Petitions and Ottoman Social Life, 16701730 (Leiden and Boston: Brill, 2004), 127-128. 
and Benedict became Mehmed. In addition, they were granted kaftâns, and kissed the sultan's hand. Afterwards, Mustafa sold his old cloths in the market for nine golden coins. ${ }^{14}$ In the same year, according to the ambassador Ungnad, a Spanish captain named Don Francisco Torellas, who served the king of Spain for many years, received an audience with the grand vizier Sokollu Mehmed Pasha, and expressed his wish to enter the service of the sultan. He converted to Islam at the Imperial Divan where he was "made a Turk and by the order of Mehmed Pasha he was named Mehmed Bey after himself." He received various gifts, including kaftân, i.e., "a golden dress like the ones given to the embassies on their departure." ${ }^{15}$ As a high-level convert, he received a yearly income of 40,000 akģes per year from the sultan's timar (fief), as well. ${ }^{16}$ In these cases, the bestowment of kaftân symbolized both the entrance into the sultan's service and the change of the identity.

What makes the Ottoman practice of donning robe of honour to non-Muslim diplomats, vassals, and other secular or religious dignitaries somewhat controversial are sharia-based sumptuary laws. A legal opinion (fetvâ) of the şeyhülislâm Ebû Su ûd Efendi (in office 1545-1574), the highest Islamic official in the Ottoman Empire during the reign of Süleymân I and his son Selîm II (r. 1566-1574), confirmed the validity of classical Islamic rulings in an Ottoman context:

Question: Is a judge who prohibits the non-Muslim subjects (zimmîs) living among the People of Islam (ehl-i İslâm) building high and decorated houses, riding horses, and wearing clothes of high value (such as) kaftâns with collar, thin muslin, fur, and turbans, and thus, performing self-aggrandising deeds in a manner insulting to the People of Islam, going to be rewarded before God?

Answer: Yes, he is. ${ }^{17}$

Some of regulations that infringed on private life of non-Muslims, such as sartorial prescriptions, were aiming at establishing and preserving clear-cut boundaries between confessional communities, as well as a visible social hierarchy. In a wider sense, the aim was to establish the order in society as a whole by preserving differences in social status, following the principle that differences in rank should be visible in dress. ${ }^{18}$ Even though types, quality and colours of prescribed non-

$14 \quad$ Stephan Gerlach, Türkiye Günlüğ̈̈ 1573-1576, trans. Turkis Noyan, ed. Kemal Beydili, Vol. 1 (Istanbul: Kitap Yayınevi, 2006), 348-349.

15 Tobias P. Graf, The Sultan's Renegades. Christian-European Converts to Islam and the Making of the Ottoman Elite, 1575-1610 (Oxford: Oxford University Press, 2017), 81.

16 Graf, The Sultan's Renegades, 82.

17 Ahmet Akgündüz, Osmanl Kanunnâmeleri ve Hukukî Tablilleri, Vol. 4 (Istanbul: Fey Vakfi, 1992), 44.

18 Donald Quataert, "Clothing Laws, State, and Society in the Ottoman Empire, 1720-1829," International Journal of Middle Eastern Studies, 29 (1997): 405-406, 419; Suraiya Faroqhi, 
Muslim robes indicated inferior social status, as can be seen also in two sultanic orders (fermâns) from $976 \mathrm{AH} / 1568 \mathrm{CE}$, which prohibit Christians and Jews dressing "high quality dress" (âlâlibâs), the main purpose was to ensure that "nonMuslims should not dress Muslim robes." ${ }^{19}$ Similarily, fermân sent to kâdî (judge) of Istanbul from $985 \mathrm{AH} / 1577 \mathrm{CE}$ affirms that non-Muslims "should not wear Muslim robes and wrap (turban) in a Muslim way." ${ }^{20}$ Fetvâ of the şeyhülislâm Esad Efendi (d. 1625; in office 1615-1622, 1623-1625) asserts a notion that distinction between confessional communities was the main concern of these prescriptions:

If the predominant dress of the zimmis of a particular region is green, and the zimmi women too wear a green garment called füstan, is the legal authority permitted to forbid the aforementioned from wearing green clothes?

Answer: No. But they must be distinguishable from Muslims. ${ }^{21}$

The government's concern for establishing clear confessional boundaries between non-Muslims is expressed in fermân of $988 \mathrm{AH} / 1580 \mathrm{CE}$ that prohibits Jews wearing Christian headgear. ${ }^{22}$ On the other hand, Muslims were prohibited to dress non-Muslim clothes, as well. According to the legal opinion of the şeybülislâm Kemâlpaşazade (d. 1534; in office 1526-1534), dressing of infidel clothes by a new Muslim of Roma origin was a transgression of sharia that has to be corrected by renewal of faith and changing of clothes. ${ }^{23}$ The Kemâlpaşazade's student and later şeyhülislâm Ebû Su' ûd Efendi ruled that a Muslim who puts Jewish hat on his head without a reason has to be punished for unbelief (küfür). ${ }^{24} \mathrm{~A}$ century later, the

"Introduction, or why and how one might want to study Ottoman clothes," in Ottoman Costumes: From Textile to Identity, ed. Suraiya Faroqhi and Christoph K. Neumann (Istanbul: EREN, 2004), 22-23, and passim; Mehmet İpşirli, "Kıyafet. Osmanlı Dönemi," Türkiye Diyanet Vakfı İslam Ansiklopedisi, Vol. 25, (Istanbul: Türkiye Diyanet Vakfi, 2002), 510-512; Aleksandar Fotić, "Između zakona i njegove primene," in Privatni život u srpskim zemljama u osvit modernog doba, ed. Aleksandar Fotić (Beograd: Clio, 2005), 67.

19 Ahmet Refik, Onuncu Asr-ı Hicrî'de İstanbul Hayatı (On Altıncı Asırda İstanbul Hayatı (15531591) (Istanbul: Enderun Kitabevi, 1988), 47-48.

20 Refik, Onuncu Asr-i Hicrîde İstanbul Hayatı, 51.

${ }^{21}$ Gayrimüslimlere Dair Fetvâlar. Osmanlı Şeyhülislâmlık Kurumu, ed. Pehlul Düzenli (Istanbul: Klasik, 2015), 35; English translation from Cornell Fleischer and Amir A. Toft, "Fetvas on NonMuslims," in The Ottoman World. A Cultural History Reader, 1450-1700, ed. Hakan T. Karateke and Helga Anetshofer (Oakland: University of California Press, 2021), 138.

22 Refik, Onuncu Asr-i Hicrîde İstanbul Hayatz, 51-52. Cf. Yavuz Ercan, "Osmanlı İmparatorluğu’nda Gayrimüslimlerin Giyim, Mesken ve Davranı̧̧ Hukuku," Osmanlı Tarihi Araştırma ve Uygulama Merkezi Dergisi 1, 1 (1990): 122.

23 Gayrimüslimlere Dair Fetvâlar, 314.

24 M. Ertuğrul Düzdağ, Şeyhülislâm Ebussun̂d Efendi Fetvaları Işı̆ğnda 16. Asır Türk Hayatı (Istanbul: Enderun Kitabevi, 1983), 118/530. 
şeyhülislâm Çatalcalı 'Alî Efendi (d. 1692; in office 1674-1686, 1692) prescribed that a Muslim who puts infidel's hat on for fun has to be punished by renewal of faith and marriage. ${ }^{25}$ To sum up, it seems that main purpose of Ottoman sumptuary laws was not necessarily discrimination of non-Muslims, but establishment of firm confessional boundaries, and visible social order, even though placing nonMuslims at its bottom can be seen as discrimination. Somewhat paradoxically, as Suraiya Faroqhi noticed, forcing non-Muslims to wear clothes of lower quality actually reduced the difference in dress between them and poor Muslims. ${ }^{26}$

Members of non-Muslim elites, especially those employed in state service, dressed as members of the ruling class ('askerî) and were exempted from nonMuslim sumptuary laws. While the sultanic order of $976 \mathrm{AH} / 1568 \mathrm{CE}$ insisted that Jews and Christians should not be dressed as Muslims, "sipâhîs (feudal cavalrymen, fief holders) and other groups, ${ }^{\prime 27}$ this ruling was obviously not binding for Christian sipâhîs, a relatively numerous group in the Western Balkans up to the sixteenth century. Christian sipâhîs and other Christian elites, such as voyvodas (headmen), knezes, and others, that collaborated with the Ottomans and entered state service, are sometimes portrayed in church paintings and frescos as donors of Christian Orthodox churches. Famous examples of such representations of Christian secular elites, connected to the Serbian Orthodox Church, i.e., the Patriarchate of Peć (İpek), are portrayals of the grand knez Vukić Vučetić in the Monastery of Assumption in Morača in Montenegro (1574), sipâhî Vojin and the goldsmith Jovan of Foča in the Monastery of Holy Trinity in Pljevlja in Montenegro (1592), sipâhî Miloslav Miloradović Hrabren in the Monastery of Annunciation in Žitomislić in Herzegovina (1609) (lost in the nineteenth century), and župan (headman) Georgi with his wife Zora and son Manojlo in the Monastery of Assumption in Krepičevac, eastern Serbia (the beginning of the sixteenth century). They were dressed in the style of Ottoman elites, donned with richly embroidered kaftâns of lively colours, fur and other precious materials otherwise prohibited to non-Muslims. ${ }^{28}$ The privilege to wear dress of the ruling class was also extended to non-Muslim individuals closely connected to the sultan and the grand vizier, such

25 Çatalcalı 'Alî Efendi, Fetâvâ-i 'Alî Efendi (Istanbul: Matbaáa-i Âmire, 1272/1892-1893), 166$167 / 7$.

26 Faroqhi, "Introduction, or why and how," 41.

27 Refik, Onuncu Asr-i Hicrî'de İstanbul Hayat, 47.

28 Zoran Rakić, "Svakodnevni život slikara 16. i 17. veka i svakodnevica u njihovim delima," in Privatni život u srpskim zemljama u osvit modernog doba, ed. Aleksandar Fotić (Beograd: Clio, 2005), 411-413; Machiel Kiel, Art and Society of Bulgaria in the Turkish Period (Assen/Maastricht: Van Gorcum , 1985), 91-93; for other examples of portrays of Bulgarian and Macedonian church donors see Kiel, Art and Society, 137-142. 
as chief physicians, as well as non-Muslim religious dignitaries such as the Orthodox Christian Patriarchs, other highly ranked clergy, and rabbinical authorities. ${ }^{29}$

In addition to elites connected to state, some other non-Muslim groups were allowed to wear "Muslim dress" under special circumstances. Merchants were allowed to don Muslim cloths during travel in dangerous places for safety concerns, as asserted by the şeybülislâm Çatalacalı 'Alî Efendi. ${ }^{30}$ This privilege was enjoyed by the Ragusan envoys and merchants, who were Ottoman vassals, and affirmed numerous times in sultanic orders and other documents. In the fermân of 1056 AH / 1646 CE, the Ragusans were allowed to wear Muslim dress such as turbans, kalpaks (Ottoman fur caps), takiyes (Ottoman skull-caps), yeleks (Ottoman waistcoats), and the like. In addition, they were allowed to carry arms, another perceived Muslim preserve. ${ }^{31}$

Another non-Muslim group that enjoyed the right to don Muslim dress on travel were the Bosnian Franciscans. In 1050 AH / 1640 CE, the vizier of Bosnia Şâhin Pasha (in office 1639-42), issued the order following the complaint of the Bosnian monks at the Bosnian court (divan-i Bosna), today preserved in the archive of the Franciscan Monastery of Holy Spirit in Fojnica. ${ }^{32}$ According to the Franciscan claim and the earlier sultanic orders presented, since the time of the imperial conquest (1463), the monks enjoyed the right to collect alms "according to their void rite" (âyin-i bâtilleri üzere) and travel on the back of saddled and bridled horses donned with dolama jackets and kalpaks and similar items, and armed with swords. Their right was denied by some wrongdoers as improper. In order to prevent such unjust acts against the Franciscans, the pasha issued a letter which confirmed their privileges and warned transgressors not to interfere. The Franciscan privileges of wearing Muslim dress and carrying arms were confirmed again in $1085 \mathrm{AH} / 1675$ CE by fermân of Sultan Mehmed IV (r. 1648-1687). ${ }^{33}$ The sultan affirmed that it is the right of Franciscans to carry swords and don Muslim dress (müslümân libâsı) based on Islamic law (şer'-i şerîf), state law (kânûn), and sultanic order (emr-i şerîf),

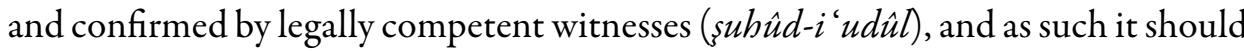
not be infringed by anyone. In addition, fetva preserved in the archive of the same monastery, confirmed the Franciscan privileges, and provided them with the authority of sharia:

29 Madeline C. Zilfi, "Women, Minorities and the Changing Politics of Dress in the Ottoman Empire, 1650-1830," in The Right to Dress. Sumptuary Laws in a Global Perspective, c. 1200-1800, ed. Giorgio Riello and Ulinka Rublack (New York, Cambridge University Press, 2019), 399. Çatalcalı 'Alî Efendi, Fetâvâ-i Alî Efendi (Istanbul: Matba'a-i Âmire, 1272/1892-1893), 161.

31 Başbakanlık Osmanlı Arşivi, Istanbul. Düvel-i Ecnebiye, Vol. 14, f. 138. See also fols. 194, 224, 307.

32 AF. Acta turcica, VII, 301.

33 AF. Acta turcica, VI, 274. 
(Question) Is it permitted by Islamic law to the infidel community to dress yelek (Ottoman waistcoats) and takiya (Ottoman skullcap) and carry arms on the road at frightful places?

(Answer) It is not forbidden. ${ }^{34}$

It seems that some local Muslims understood that general sharia based sumptuary laws and zimmî regulations were transgressed by the Franciscans by donning Muslim dress and carrying arms, and therefore they tried to prevent them from doing so. The provincial and central authorities, however, recognized the Franciscan privileges that were based primarily on special arrangements, imperial edicts, and kânun, and fortified by the authority of an Islamic law scholar in fetvâ.

Donning luxurious cloths and carrying expensive arms by the monks, however, was disapproved by the Franciscan authorities as well. According to the Franciscan chronicler Jako Baltić, in 1769, the Franciscan assembly (definitorium) held in the Monastery of Kreševo, issued a decree that secular dress of the monks in Bosnia, which was permitted by the Holy See, has to be "simple, humble, and of low price, without any pride and luxury of the seculars." 35 Ten years later, in 1779, in the assembly in the Monastery of Sutjeska, the monks were urged to dress adequate to their status, while carrying long and curved knives peculiar to the Jannisaries was strictly forbidden. ${ }^{36}$ According to the official protocol, the assembly

warns against unacceptable expense of some friars, especially those who live in parishes and carry arms outside of the courtyard. In addition, the venerable assembly warns against glamorous luxury of arms of rich brilliance and decorations carried by the friars.... The belts for carrying pistols, called silaije among people, are embroidered with gold, although seemingly artificial, because these arms are not carried for defence of one's own life, but more for the sake of pure boasting and showing of frivolous wastefulness. Therefore, for the sake of decency and solving of this dangerous expanse in general, under the threat of removal from all duties and monastic honours, the venerable assembly orders with this letter all present fathers and friars to wear these arms as long as there is need for it, but without same decorations and shiny colours. Likewise, the venerable assembly, under the threat of same punishments, forbids all fathers and friars carrying knives called jatagani (yatagans), because in that manner the janissaries are bringing death. In addition, the venerable assembly forbids shooting from pistols and rifles, as some fathers

\footnotetext{
$34 \quad$ AF. Acta turcica, IX B, 1744.

35 Jako Baltić, Godišnjak od dogadaja crkvenih, svjetskih i promine vrimena u Bosni (Sarajevo: Veselin Masleša, 1991), 35. 
and friars used to do, until the moment of approaching a village, or, if they were to stay overnight, to indicate their coming. ${ }^{37}$

Here, the luxuriousness of belts and arms irreconcilable with the monastic call seem to be the target of the ban.

Sumptuary laws in Bosnia in the same period, however, were confirmed in two documents prescribing appropriate dress for non-Muslim subjects of Sarajevo. The museum of the old Serbian Orthodox Church in Sarajevo preserved a church announcement from the year of 1777, which warned the Orthodox Christians of Sarajevo not to transgress Ottoman sumptuary prescriptions following the request of the authorities. ${ }^{38}$ Women were urged to cover and not to dress showily; if they did, then they were urged to stay at home. Christians were warned not to embellish their female children with golden coins. They were especially warned not to dress Turkish or başa's (local Jannisary) garments, because the lords cannot look at that. In a similar manner, fermân of 1794 warned Christians and Jews of Sarajevo to dress clothes and colours prescribed to their communities, or they will face imprisonment. ${ }^{39}$ Christians were prescribed to wear blue, black and dark blue broadcloth, while Jews were obliged to wear blue boots and slippers, as well as other cloths like Christians. The main concern of the sultan was the fact that Muslims were not distinguishable by dress from non-Muslim $r e^{e}$ ây $\hat{a}$ any more.

According to the documents issued to the Franciscans that asserted their exemption from sumptuary laws, it seems that they were not regarded as commoners despite being non-Muslims. In general, to surprise of some contemporaries, Ottoman sumptuary laws did not arrange distinction between individuals solely on the basis of religion, but according to their rank in society. Muslim and non-Muslim commoners, réâyâ, were not allowed to dress as sipâhîs, while sipâhîs were not allowed to dress as religious dignitaries, and so on. Lütfî Pasha (d. 1562), former grand vizier, in his political tractate called Asâfnâme, in the chapter concerning the status of réây $\hat{a}$ quotes a ruling that réây $\hat{a}$ is prohibited from wearing clothes of high quality such as those of sipâhîs. ${ }^{40}$ In this case, the aim was to establish a strict demarcation between the ruling class, 'askerîs, and the subject class, réâyâ. An elaborated system of dress and headgear served for precisely establishing the social rank of an individual. In this sartorial system, each professional, social, confessional, and

Archive of the Franciscan Province of Bosna Srebrena, Protocollum I, fols. 370-371, according to Mario Šain, “'Turska pravda' - osmansko pravo u izvorima Franjevačke provincije Bosne Srebrene u 18. st.," MA thesis (Faculty of Humanities and Social Sciences, University of Zagreb, 2017), 86.

38 Vladimir Skarić, "Jedna naredba o rajinom odijelu iz doba otomanske vladavine," Glasnik Zemaljskog muzeja u Sarajevu 14 (1902): 557.

39 Salih Sidki Hadžihuseinović Muvekkit, Povijest Bosne, trans. Abdulah Polimac, Lamija Hadžiosmanović, Fehim Nametak, and Salih Trako, Vol. 2 (Sarajevo: El-Kalem, 1999), 722-723. 
ethnic group had its own code. ${ }^{41}$ In the later period, in the mid-eighteenth and early nineteenth centuries, the divide line between 'askerî and re'âyâ was further strengthened by harsh measures for the offenders of sumptuary decrees. ${ }^{42}$

After receiving official recognition via sultanic decrees and being donned robe of honour, such non-Muslim individuals were regarded as state servants, and, as a consequence, were exempted from discriminating sharia-based regulations. ${ }^{43}$ According to the Franciscan chronicles, the ceremony of donning the Franciscans with robe of honour was re-enacted three centuries after the conquest of Bosnia. In 1758, the heads (guardians) of the Franciscan monasteries of Fojnica, Kreševo, and Sutjeska, according to the chronicler Bonaventura Benić, visited the governor of Bosnia, Mehmed Pasha Kukavica (Kukavičić, Kovaca el-Hac Mehmed Pasha, the governor of Bosnia 1752-1756, 1757-1760) ${ }^{44}$ in Travnik in order to submit cülùs, a tax that was paid to newly appointed governors, or given every year. Upon the payment of the tax, they were cloaked with robe of honour called binis (binjiš). According to the chronicler Benić, who was himself an eyewitness as the deputy of the guardian of the Monastery of Sutjeska, kethüdâ told us:

"the pasha wants to cloak you with binişes." We pleaded that we are not for that - "we are poor." Kethüdâ sent selam aga to the pasha to report our sayings. The pasha told him: "Tell these cowards (šaškin) not to be afraid. I am not asking anything in return, nor does any of my people; I want to give to them so that everybody knows that the great Turks love them." He gave each of us one biniş to dress. The ceremony to be conducted while dressing is as follows: the pasha's skirt has to be kissed, then biniş, and after that it has to be dressed. There are the masters of the ceremony who teach and dress; these are, brother, hard accounts. After dressing up, we were sent to kethüdâ for a coffee; one year ... we drank it in front of the pasha; it was hard to drink, and one gets sweaty. ${ }^{45}$

41 Cf. İpşirli, "Kıyafet," 510-512; Mübahat S. Kütükoğlu, Osmanlinın Sosyo-Kültürel ve İktisâdî Yapısı (Ankara: Türk Tarih Kurumu, 2018), 187-188; Faroqhi, "Introduction, or why and how," 23.

42 Zilfie, "Women, Minorities and the Changing Politics of Dress," 398-399.

43 Vjeran Kursar, "Some Remarks on the Organization of Ottoman Society in the Early Modern Period: The Question of 'Legal Dualism' and Societal Structures," in Perspectives on Ottoman Studies. Papers from the 18th Symposium of the International Committee of Pre-Ottoman and Ottoman Studies (CIEPO) at the University of Zagreb 2008, ed. Ekrem Čaušević, Nenad Moačanin and Vjeran Kursar (Berlin: LIT Verlag, 2010), 846-847.

44 On Mehmed Pasha Kukavica see: Alija Bejtić, "Bosanski namjesnik Mehmed paša Kukavica i njegove zadužbine u Bosni (1752-1756 i 1757-1760)," Prilozi za orijentalnu filologiju 6-7 (19561957): 77-114; Michael Robert Hickok, Ottoman Military Administration in Eighteenth-Century Bosnia (Leiden, New York, and Cologne: Brill, 1997), 119-136.

45 Bono Benić, Ljetopis sutjeskegga samostana, ed. with Latin and Italian sections trans. Ignacije Gavran, (Sarajevo and Zagreb: Synopsis, 2003), 202. 
Unaccustomed to favourable treatment and generous reception, the Franciscans were astonished by the ceremony. Benić wrote that "this was the first pasha who showed such an honour to us friars, which was never heard before." ${ }^{\text {"U Upon seeing }}$ the Franciscans dressed in robe of honour in the streets of Travnik, local, obviously Muslim, shop keepers were surprised as well, some of them in a negative way. A year later, however, the guardians were honoured with binişes again by the pasha. ${ }^{47}$ In 1780, another governor of Bosnia, Defterdâr 'Abdullah Pasha (Paša TefterdarovićSarajlija, 1780-85), during the reception and following the payment of the cülùs tax, presented the guardians of the three monasteries with binişes yet again, and granted them a favourable edict. ${ }^{48}$ Binişes were granted to the Franciscan heads by new pashas in 1785 and 1786, as well. ${ }^{49}$ The ceremony of donning binişes to the heads of Franciscan monasteries continued until 1847, while the last Bosnian governor who performed the ceremony was Mehmed Tahir Pasha. ${ }^{50}$ In a letter to the vizier of Bosnia in 1843, for example, the Bosnian bishop Rafo Barišić, who was in conflict with the Bosnian Franciscans, wrote that because of his faithfulness to the authorities, he was cloaked with biniş by earlier vizier, "which was a favor that was shown to no other bishop from Bosnia." 51

Although the value of robe of honour presented to the Franciscans according to Benić was estimated to amount to 50 groš / kuruş, $^{52}$ which was a significant sum, it is not possible to exactly compare the second half of the eighteenth century biniş with hil'at / kaftân given to Anđeo Zvizdović by the sultan Mehmed II three centuries earlier. The fact that the number of hil'ats has been inflating since the middle of the sixteenth century, ${ }^{53}$ however, might indicate the lower quality of binişes of the eighteenth century, as well as lesser exceptionality and, therefore, significance, of the ceremony itself. While hil'at as a generic term denotes any type of robe of honour, a more specific biniş was usually bestowed on medium-to-higher ranked officials and members of 'ulemâa', and was made of wool (winter versions) or linen (summer version), ${ }^{54}$ which might also indicate its inferiority to the silk-made and gold-embroidered item presented to Zvizdović. Finally, the person of the donor (sultan vs. governor) must have determined the significance of the gift itself. In 1783, the Franciscan

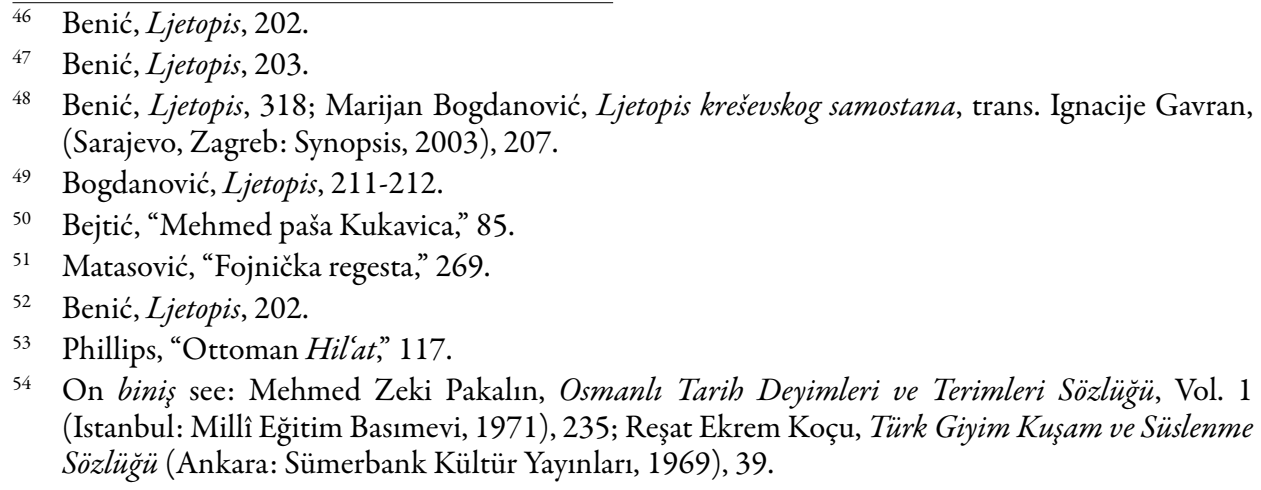

48 Benić, Ljetopis, 318; Marijan Bogdanović, Ljetopis kreševskog samostana, trans. Ignacije Gavran, (Sarajevo, Zagreb: Synopsis, 2003), 207.

4 Bogdanović, Ljetopis, 211-212.

50 Bejtić, "Mehmed paša Kukavica," 85.

51 Matasović, "Fojnička regesta," 269.

52 Benić, Ljetopis, 202.

53 Phillips, “Ottoman Hil'at," 117.

54 On binişs see: Mehmed Zeki Pakalın, Osmanl Tarih Deyimleri ve Terimleri Sözlügü, Vol. 1 (Istanbul: Millî Eğitim Basımevi, 1971), 235; Reşat Ekrem Koçu, Türk Giyim Kuşam ve Süslenme Sözlüğ̈̈ (Ankara: Sümerbank Kültür Yayınları, 1969), 39. 
envoy to Istanbul, Josip Tomić from Kreševo, managed to obtain a very favourable ferman from the sultan. During the reception at the court, he was donned kaftan (cavtan), and had to pay 3 kuruş as bahşis ("tip") to the person who performed the donning, as asserted in his account of the expenses of the fermann. ${ }^{55}$

Few items belonging to the category of Ottoman robe of honour is preserved in the region today. According to Jelena Ivoš, the author of the text about textile in the catalogue of the exhibition "Franciscans on the Crossroad of Cultures and Civilizations" held in Zagreb, in 1988-1989, only three textile items in the Franciscan monasteries in Bosnia and Herzegovina can be identified as Ottoman in origin. ${ }^{56}$ The most famous is the legendary kaftân of Anđeo Zvizdović, today reshaped into a cloak, made of dark blue-green atlas silk with motives of flowers and stars embroidered in gold, in dimensions $117 \times 140 \mathrm{~cm} .{ }^{.7}$ Despite scepticism of some historians, the radiocarbon (Carbon 14) dating of its textile conducted in Institute "Ruđer Bošković" in 2013 established that the cloak is younger than the alleged time of the encounter of the sultan Mehmed II and Fr. Anđeo Zvizdović, given the calibrated age span is 1492-1641, with probability $95.4 \%$. However, partial overlapping of the individual measurements of 'ahdnâme and the cloak, i.e., the lower part of 'ahdname and the outer layer of the cloak, could suggest the cloak belong to the time of the conquest of Bosnia. ${ }^{58}$ The lining material of the cloak, however, belongs to the younger age span (1652-1805, with probability $74.7 \%)$, which, interestingly enough, agrees with the calibrated age span of the upper, attached part of the paper of 'abdnâme, and suggest that the renovation of the two was perhaps conducted at the same time. ${ }^{59}$

The story of the ceremonial robe in its written form appeared for the first time in the chronicle of the Slavonian Franciscan Ivan Stražemanac (Ioannes a Straxemano, d. 1758) in the eighteenth century. In the list of the Franciscans famous for their holiness and wonders, Stražemanac included the Blessed Anđeo, who converted many schismatics and died in Fojnica in 1498:

After the monastery was turned to ashes by the Turks, and only the empty walls remained, the body of Father Andeo was found. When a Turk saw him so beautiful, preserved, and flexible, he immediately undressed his own robe and covered the body of the Blessed. Later the

55 Julijan Jelenić, Izvori za kulturnu povijest bosanskih franjevaca (Sarajevo: Zemaljska štamparija, 1913), 56; Vjeran Kursar, "Bosanski franjevci i njihovi predstavnici na osmanskoj Porti," Prilozi za orijentalnu filologiju 60 (2011): 381-383.

56 Katalog izložbe Franjevci Bosne i Hercegovine na raskršću kultura i civilizacija. Blago franjevačkih samostana Bosne i Hercegovine (Zagreb: MGC, 1988), 159, 161.

57 Katalog izložbe Franjevci, 161, 230, No. 331.

58 Horvatinčić, Sironić, Barešić and Kozjak, "Radiocarbon dating of Ahdname," 1366-1368.

59 Horvatinčić, Sironić, Barešić and Kozjak, "Radiocarbon dating of Ahdname," 1367-1368. 
brothers made a pretty ceremonial cloak from the robe, which is until today kept in that sacristy. ${ }^{60}$

Although this fantastic story does not fit a narrative of Ottoman practice of bestowing kaftan along with granting privileges in the form of imperial edict, it contains several elements which might correlate with the known historical data. The cloak preserved today in the museum of the Monastery of Fojnica is not in the shape of kaftân, but is remodelled into a cloak, as Boškov suggested, ${ }^{61}$ which corresponds to the Stražemanac's information that the robe of a Turk was used by the friars to make a ceremonial cloak. In addition, if a later dating of the cloak is right, and it does not belong to 1463 or 1464 when the conquest was conducted and the alleged encounter between the sultan and the monk took place, this would correspond with the information from the Stražemanac's chronicle that a Turk used his robe to cover the newly discovered body of Zvizdović following one of the fires of the monastery in the early sixteenth century. ${ }^{62}$

According to the catalogue of the exhibition, another two remaining examples of robe of honour are liturgical vestments from the eighteenth century preserved in the museum of the Monastery in Sutjeska, namely a dalmatic made of red-pink atlas silk embroidered in gold and silver with floral motive, in dimensions $106 \times 122 \mathrm{~cm}$, and a chasuble made of ivory-coloured atlas silk embroidered in gold with floral motives, in dimensions $113 \times 76 \mathrm{~cm} .{ }^{63}$ One more chasuble of Ottoman origin from the eighteenth century is preserved in the museum of the Monastery of Sutjeska as well, according to information and a photograph provided to the author by late Fr. Stjepan Durnjak, the head of the museum..$^{64}$ It is made of light green material embroidered in gold with floral motives, in dimensions $105 \times 69 \mathrm{~cm}$.

It is possible that more items remained unrecognized in other church textile collections, since, as claimed by Ivoš,

in defining the stylistic features of the textiles in Bosnia and Herzegovina, experts are faced with the problem of identifying those fabrics of European origin and those of Turkish provenance. This area

60 Ivan Stražemanac, Povijest Franjevačke provincije Bosne Srebrene 1730, trans. Stjepan Sršan (Osijek: Pax et bonum, 2010), 55.

${ }^{61}$ Boškov, "Pitanje autentičnosti Fojničke ahd-name," 92.

62 See Mijo V. Batinić, Franjevački samostan u Fojnici: od stoljeća XIV.-XX. (Zagreb, 1913), 130-131; Vrgoč, "Fra Anđeo Zvizdović," 21-22.

63 Katalog izložbe Franjevci, 161, 231, nos. 343 and 344.

64 Email correspondence with Fr. Stjepan Duvnjak, April 2021. The museum catalogue of textile done by Jelena Ivoš, item no. 61. I am grateful to Fr. Stjepan for this information, as well as for help he provided me two times I visited the monastery's archive and library. He will be remembered as a great and knowledgable archivist, librarian, scholar, and, above all, a very kind and helpful person. 
was abundant in luxurious Oriental fabrics, with the result that ecclesiastical raiment was often made of Turkish, and even Persian, silks. ${ }^{65}$

The problem of identification is further complicated by the fact that many of the fifteenth-to-seventeenth century velvet ceremonial kaftâns preserved in the museum of Topkapı Palace, the great Ottoman Seraglio, were imported from Italy, while the design of domestic Ottoman kaftâns in general is very similar to the Italian, if not its imitation. ${ }^{66}$ One such item of ambiguous identity from the fifteenth century is the so-called cape of Stjepan Tomašević (1461-1463), the last Bosnian king, preserved as the chasuble in the Franciscan Monastery of Zaostrog in Dalmatia, which was until the Peace of Karlowitz in 1699 part of the Ottoman Empire, and until 1735 inside the borders of the Franciscan Province of Bosnia (Bosna Srebrena). The chasuble is made of "rare silk atlas embroidered with gold with the large stylized carnations characteristic of oriental, especially Turkish, textiles." ${ }^{67}$ Recently Ivana Svedružić Šeparović confirmed Ottoman kaftân origin of the chasuble. She linked it not with the last Bosnian king, but his step-mother queen Katarina (d. 1478), the wife of his father king Stjepan Tomaš (1443-1461), herself a refugee in the time of the Ottoman conquest. ${ }^{68}$ The alleged portray of King Stjepan Tomaš in the painting entitled "Christ and Donor" done by the Ragusan painter Lovro Dobrićević around 1460, today preserved in the Strossmayer's Gallery of Old Masters of Croatian Academy of Sciences and Arts in Zagreb, provides an opportunity to see what the robe of the Bosnian king in the mid-fifteenth century might have looked like. ${ }^{69}$

The practice of converting Ottoman robe of honour as a highly appreciated luxurious objects into ecclesiastical textiles and chasubles was widely spread in both Roman Catholic and Christian Orthodox churches. Ragusan diplomats who received kaftâns (veste turcicae dictae caftani) during reception at the Ottoman court were obliged to deposit the gifts to the chamberlain of the Republic in Dubrovnik. In this manner over 150 kaftâns were obtained. Kaftâns were later donated to the

65 Katalog izložbe Franjevci, 161.

66 Louise W. Mackie, "Ottoman Kaftans with an Italian Identity," in Ottoman Costumes. From Textile to Identity, ed. Suraiya Faroqhi and Christoph K. Neumann (Istanbul: Eren, 2004), 219229; Tülay Artan, "Objects of Consumption: Mediterranean Interconnections of the Ottomans and Mamluks," in A Companion to Islamic Art and Architecture. Volume II. From the Mongols to Modernism, ed. Finbarr Barry Flood and Gülrü Necipoğlu (Hoboken: Wiley \& Sons, 2017), 908.

67 Katalog izložbe, 161.

68 Ivana Svedružić Šeparović, "Komplet liturgijskog ruha iz franjevačkog samostana u Zaostrogu," in VI. Zbornik Dana Cvita Fiskovića (Zagreb: FF Press, 2016), 116-126.

69 Ljerka Dulibić, "Lovro Dobričević (Kotor, oko 1420. - Dubrovnik, 1478), Krist i donator, 1460. (?)," in Strossmayerova galerija starih majstora - odabrana djela, ed. Ljerka Dulibić, Iva Pasini Tržec, Borivoj Popovčak (Zagreb: Hrvatska akademija znanosti i umjetnosti, 2013), 56-61; Ivana Prijatelj Pavičić, "Priloz poznavanju sudbine slike uskrslog Krista i kralja Stjepana Tomaša porijeklom iz Kraljeve Sutjeske," in Stoljeća Kraljeve Sutjeske, ed. Marko Karamatić (Kraljeva Sutjeska - Sarajevo: Franjevački samostan Kraljeva Sutjeska - Kulturno-povijesni institut Bosne Srebrene, 2010), 105-139. 
churches in the territory of the Republic of Dubrovnik, where they were reshaped into chasubles, or, more rarely, into other liturgical textiles. ${ }^{70}$ Since 1530 , all ceremonial dresses bestowed to the Venetian diplomats in Istanbul were handed over to the treasury of San Marco, likewise. ${ }^{71}$ Similarly, Orthodox churches in Wallachia and Moldavia, the Ottoman vassal states whose rulers were receiving kaftâns from the sultan on regular basis, profited from these popular luxurious gifts, which were turned into liturgical textiles in return. ${ }^{72}$ The Greek Orthodox Church, i.e., the Oecumenical Patriarchate of Constantinople, applied this practice as well. During the legendary ceremony of appointing the first patriarch in the conquered town in 1454, which resembles a decade later Bosnian encounter with Fr. Anđeo Zvizdović, Sultan Mehmed II presented the new patriarch Gennadios Scholarios with berât as the document of the appointment, as well as, among other insignia objects, a ceremonial kaftân. ${ }^{73}$ The Church was ready to accept the extravagant gift. In time it appropriated Ottoman textile culture without reservation, and used and reused Ottoman robes of honour for liturgical and decorative purposes, whether as dress or covers and hangings. ${ }^{74}$ In general, it seems that Ottoman fashion and aesthetics was appealing to the Christian taste and was eventually appropriated by the Christian Churches, notwithstanding all differences and rivalries.

Hil'ats were granted by state authorities as a sign of recognition to the servants, officers, and diplomats of different ranks on various occasions, sometimes en masse. The examples from the mid-seventh century provided by the famous Ottoman traveller Evliyâ Çelebî (d. after 1683) are both overwhelming and insightful. Concerning the region under discussion, Evliyâ provides several illustrative examples. In 1660, the warden of the tower (kule) in Prolog near Livno (İhlevne) by the name of Baba Ahmed was granted hil'at for his exceptional military service by the governor of Bosnia Melek Ahmed Pasha. ${ }^{75}$ Similarly, military commanders that managed to break the enemy siege of the fortified town of Knin in 1654, were given fahrî bil'ats by the governor Fazlî Pasha (Fadil Ahmed Pasha). ${ }^{76}$ The commanders of the Bosnian sancaks during consultation in Kupres (Köprez) received hilats from

70 Verena Han, "Turski počasni kaftan u službi hrišćanske liturgije na Balkanu (XVI-XVII vek)," in Gradska kultura na Balkanu (XV-XIX vek), ed. Verena Han (Belgrade: Srpska akademija nauka i umetnosti, 1984), 279-281.

71 Hedda Reindl-Kiel, "Audiences, Banquets, Garments and Kisses. Encounters with the Ottoman Sultan in the 17th Century," in The Ceremonial of Audience. Transcultural Approaches, ed. Eva Orthmann and Anna Kollatz (Göttingen: Bonn University Press, 2019), 189.

72 Han, “Turski počasni kaftan,” 285.

73 Vryzidis, “Textiles and Ceremonial," 61.

74 Vryzidis, "Textiles and Ceremonial," 61-80.

75 Evliya Çelebi, b. Derviş Mehemmed Zıllî, Evliya Çelebi Seyahatnâmesi. Topkapı Sarayı Bağdat 307 Yazmasinın Transkripsyonu - Dizini, edited by Yücel Dağl, Seyit Ali Kahraman, İbrahim Sezgin, Vol. 5 (Istanbul: Yapı Kredi Yayınları, 2001), 240.

76 Evliya Çelebi, Evliya Çelebi Seyahatnâmesi, Vol. 5, 243. 
Melek Ahmed Pasha, as did Yûsuf Kethüdâ upon his promotion to the commander over 10,000 soldiers in Vrpoljica. ${ }^{77}$ Following the great victory over the enemy, the pasha granted no less than 170 gilded hil'ats to commanders of various ranks and servants. ${ }^{78}$ Evliyâ Çelebî himself was granted hil'at along with 300 golden coins by the sultan in Istanbul, as a recognition for his services in the enemy territory in Croatia, where he managed to negotiate the release of the captain of Bihać (Bihke) from the captivity in Čakovec, and to collect valuable information concerning the forthcoming war in Erdel with Rákóczy. ${ }^{79}$

The Muslim chronicler of Sarajevo, Mollâ Mustafâ Başeski (Bašeskija; d. 1809) provides a local information on the donning of robe of honour on several occasions in the second half of the eighteenth century. Upon his arrival in Travnik as the new governor of Bosnia in 1775, Ayvazzade Hâcî Halîl Pasha "granted a lot of hil'ats." In 1777, the governor Dagestanlı 'Alî Pasha presented binişes to agas in Sarajevo. He did not, however, accept the petition of thirty-four 'alemdârs who asked for hil'ats for themselves. ${ }^{81}$ In 1778, Silâhdâr Mehmed Pasha, as the new governor of Bosnia, granted a lot of hil'ats to agas and 'alemdârs in Sarajevo. ${ }^{82}$ A year later, the new governor, Nişâncı Pasha, gave 120 bil'ats to the elites gathered in Travnik, which included various dignitaries such as agas, 'alemdârs, kâdîs, and çavuşes. In addition to hil'at, Başeski mentioned other types of robe of honour as well: kaput, kontoş and biniş, including the binişes made of Frankish broadcloth. ${ }^{83}$

\section{CONCLUSION}

Bestowing robe of honour on the Franciscan leaders indicate that they were, at least occasionally, officially treated and recognized as state servants. The type of robe of honour ascribed to the Franciscans in the second half of the eighteenth century, biniş, allows us to approximately determine the rank they might have had in the Ottoman hierarchy, next to dignitaries such as agas, 'alemdârs, and perhaps

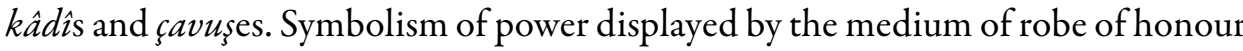
was not an empty gesture. In addition to robe of honour, which was preserved for the heads of the monasteries, ordinary friars were exempted from sumptuary laws, unlike ordinary subjects (réây $\hat{a}$. The above-mentioned examples indicate that the status of the Bosnian Franciscans, especially those in top positions in the order, differed from the status of commoners, and, along with various exemptions from

Evliya Çelebi, Evliya Çelebi Seyahatnâmesi, Vol. 5, 248, 251.

78 Evliya Çelebi, Evliya Çelebi Seyahatnâmesi, Vol. 5, 258.

79 Evliya Çelebi, Evliya Çelebi Seyahatnâmesi, Vol. 5, 287.

80 XVIII. Yüzyıl Günlük Hayatına Dair Saraybosnalı Molla Mustafänın Mecmuası, ed. Kerima Filan (Sarajevo: Connectum, 2011), 119.

81 XVIII. Yüzynl Günlük, 132.

82 XVIII. Yüzynl Günlük, 137.

83 XVIII. Yüzynl Günlük, 144. For kaput and kontoş see Koçu, Türk Giyim, 146, 158. 
sumptuary laws and sartorial privileges, symbolized an existence of a special arrangement with the state, if not direct enrolment in state service or membership in the ruling class.

\section{BIBLIOGRAPHY}

\section{UNPUBLISHED ARCHIVAL SOURCES}

Archive of the Franciscan Monastery of Holy Spirit, Fojnica, Bosnia and Herzegovina (AF).

Acta turcica, VI, VII, IX B, Rasuto.

Başbakanlık Osmanlı Arşivi, Istanbul.

Düvel-i Ecnebiye, vol. 14.

\section{PUBLISHED SOURCES AND LITERATURE}

XVIII. Yüzyıl Günlük Hayatına Dair Saraybosnalı Molla Mustafänın Mecmuası. Edited by Kerima Filan. Sarajevo: Connectum, 2011.

Akgündüz, Ahmet. Osmanl Kanunnâmeleri ve Hukukî Tahlilleri. Vol. 4. Istanbul: Fey Vakfi, 1992.

Artan, Tülay. "Objects of Consumption: Mediterranean Interconnections of the Ottomans and Mamluks." In A Companion to Islamic Art and Architecture. Volume II. From the Mongols to Modernism, edited by Finbarr Barry Flood and Gülrü Necipoğlu, 903-930. Hoboken: Wiley \& Sons, 2017.

Baer, Marc David. Honored by the Glory of Islam: Conversion and Conquest in Ottoman Empire. Oxford: Oxford University Press, 2008.

Baltić, Jako. Godišnjak od dogadaja crkvenih, svjetskih i promine vrimena u Bosni. Sarajevo: Veselin Masleša, 1991.

Batinić, Mijo V.. Franjevački samostan u Fojnici: od stoljeća XIV.-XX.. Zagreb, 1913.

Bejtić, Alija. "Bosanski namjesnik Mehmed paša Kukavica i njegove zadužbine u Bosni (1752-1756 i 1757-1760).” Priloziza orijentalnu filologiju 6-7 (19561957): 77-114.

Benić, Bono. Ljetopis sutjeskoga samostana. Edited and with Latin and Italian sections translated by Ignacije Gavran. Sarajevo and Zagreb: Synopsis, 2003.

Bogdanović, Marijan. Ljetopis kreševskog samostana. Translated by Ignacije Gavran Sarajevo, Zagreb: Synopsis, 2003.

Boškov, Vančo. "Pitanje autentičnosti Fojničke ahd-name Mehmeda II iz 1463. godine." Godišnjak Društva istoričara Bosne i Hercegovine 28-30 (19771979): 87-105. 
Çatalcalı 'Alî Efendi. Fetâvâ-i 'Alì Efendi. Istanbul: Matbaá-i Âmire, 1272/18921893.

Dulibić, Ljerka. "Lovro Dobričević (Kotor, oko 1420. - Dubrovnik, 1478), Krist i donator, 1460.(?)." In Strossmayerova galerija starih majstora - odabrana djela, edited by Ljerka Dulibić, Iva Pasini Tržec, Borivoj Popovčak, 56-65. Zagreb: Hrvatska akademija znanosti i umjetnosti, 2013.

Düzdağ, M. Ertuğrul. Şeyhülislâm Ebussû̂d Efendi Fetvaları Işı̆ğında 16. Asır Türk Hayatı. Istanbul: Enderun Kitabevi, 1983.

Džaja, Srećko M.. "Fojnička ahdnama u zrcalu paleografije, pravne povijesti i politike." Bosna Franciscana 17, no. 31 (2009): 103-128.

Džaja, Srećko M.. Konfesionalnost $i$ nacionalnost Bosne $i$ Hercegovine. Predemancipacijski period 1463-1804. Sarajevo: Svjetlost, 1990.

Ercan, Yavuz. "Osmanlı İmparatorluğu’nda Gayrimüslimlerin Giyim, Mesken ve Davranış Hukuku.” Osmanl Tarihi Araştırma ve Uygulama Merkezi Dergisi 1, no. 1 (1990): 117-125.

Evliya Çelebi, b. Derviş Mehemmed Zillî, Evliya Çelebi Seyahatnâmesi. Topkapı Sarayı Bağdat 307 Yazmasının Transkripsyonu - Dizini. Editeb by Yücel Dağlı, Seyit Ali Kahraman, İbrahim Sezgin, vol. 5. Istanbul: Yapı Kredi Yayınları, 2001.

Farqohi, Suraiya. "Introduction, or why and how one might want to study Ottoman clothes," In Ottoman Costumes: From Textile to Identity, edited by Suraiya Faroqhi and Christoph K. Neumann, 15-48. Istanbul: EREN, 2004.

Gayrimüslimlere Dair Fetvâlar. Osmanlı Şeyhülislâmlık Kurumu. Edited by Pehlul Düzenli. Istanbul: Klasik, 2015.

Gerlach, Stephan. Türkiye Günlüğ̈̈ 1573-1576. Translated by Turkis Noyan, edited by Kemal Beydili, vol. 1. Istanbul: Kitap Yayınevi, 2006.

Graf, Tobias P.. The Sultan's Renegades. Christian-European Converts to Islam and the Making of the Ottoman Elite, 1575-1610. Oxford: Oxford University Press, 2017.

Faroqhi, Suraiya. "Introduction, or why and how one might want to study Ottoman clothes." In Ottoman Costumes: From Textile to Identity, edited by Suraiya Faroqhi and Christoph K. Neumann, 15-48. Istanbul: EREN, 2004.

Fleischer, Cornell and Amir A. Toft. "Fetvas on Non-Muslims." In The Ottoman World. A Cultural History Reader, 1450-1700, edited by Hakan T. Karateke and Helga Anetshofer, 134-143. Oakland: University of California Press, 2021.

Fotić, Aleksandar. "Između zakona i njegove primene." In Privatni život u srpskim zemljama u osvit modernog doba, edited by Aleksandar Fotić, 27-71. Beograd: Clio, 2005. 
Han, Verena. “Turski počasni kaftan u službi hrišćanske liturgije na Balkanu (XVIXVII vek)." In Gradska kultura na Balkanu (XV-XIX vek), edited by Verena Han, 276-289. Belgrade: Srpska akademija nauka i umetnosti, 1984.

Hickok, Michael Robert. Ottoman Military Administration in Eighteenth-Century Bosnia. Leiden, New York, and Cologne: Brill, 1997.

Horvatinčić, Nada, Andreja Sironić, Jadranka Barešić and Igor Kozjak. "Radiocarbon dating of Ahdname, Mantel, and Armorial from the Fojnica Franciscan Monastery, Bosnia and Herzegovina." Radiocarbon 59, no. 5 (2017): 1359-1368.

İpşirli, Mehmet. "Kıyafet. Osmanlı Dönemi." Türkiye Diyanet Vakfı İslam Ansiklopedisi. Vol. 25, 510-512. Istanbul: Türkiye Diyanet Vakfi, 2002.

Jelenić, Julijan. Izvori za kulturnu povijest bosanskih franjevaca. Sarajevo: Zemaljska štamparija, 1913.

Jelenić, Julijan. Kultura i bosanski franjevci. Vol. 1. Sarajevo, 1912; reprint: Sarajevo: Svjetlost 1990.

Katalog izložbe Franjevci Bosne i Hercegovine na raskršću kultura i civilizacija. Blago franjevackkih samostana Bosne i Hercegovine. Zagreb: MGC, 1988.

Kiel, Machiel. Art and Society of Bulgaria in the Turkish Period. Assen/Maastricht: Van Gorcum, 1985

[Antun Knežević]. Bosanski prijatelj. Vol. 4. Zagreb: Knjižara Svetozara Galca, 1870. Koçu, Reşat Ekrem. Türk Giyim Kuşam Ve Süslenme Sözlüğ̈̈. Ankara: Sümerbank Kültür Yayınları, 1969.

Kursar, Vjeran. "Some Remarks on the Organization of Ottoman Society in the Early Modern Period: The Question of 'Legal Dualism' and Societal Structures." In Perspectives on Ottoman Studies. Papers from the 18th Symposium of the International Committee of Pre-Ottoman and Ottoman Studies (CIEPO) at the University of Zagreb 2008, edited by Ekrem Čaušević, Nenad Moačanin and Vjeran Kursar, 837-856. Berlin: LIT Verlag, 2010.

Kursar, Vjeran. "Bosanski franjevci i njihovi predstavnici na osmanskoj Porti." Prilozi za orijentalnu filologiju 60 (2011): 371-408.

Kütükoğlu, Mübahat S.. Osmanlinın Sosyo-Kültürel ve İktisâdî Yapısı. Ankara: Türk Tarih Kurumu, 2018.

Mackie, Louise W.. “Ottoman Kaftans with an Italian Identity.” In Ottoman Costumes. From Textile to Identity, edited by Suraiya Faroqhi and Christoph K. Neumann, 219-229. Istanbul: Eren, 2004.

Majda, T.. "Libās. IV - Turkey." Encyclopaedia of Islam, new edition. Vol. 5, 750-752. Leiden: Brill, 1986.

Mandić, Dominik. "Autentičnost Ahd-name Mehmeda II B.H. franjevcima." Radovi Hrvatskog Povijesnog Instituta u Rimu, 3-4 (1971): 61-90. 
Matasović, Josip. “Fojnička regesta." Spomenik Srpske kraljevske akademije 67, drugi razred 53, (1930): 61-431.

Minkov, Anton. Conversion to Islam in the Balkans: Kisve Bahast Petitions and Ottoman Social Life, 1670-1730. Leiden and Boston: Brill, 2004.

Miović, Vesna. Dubrovačka diplomacija u Istambulu. Zagreb and Dubrovnik: Hrvatska akademija znanosti i umjetnosti, Zavod za povijesne znanosti u Dubrovniku, 2003.

Pakalın, Mehmet Zeki. Osmanlı Tarih Deyimleri ve Terimleri Sözlüğ̈̈. Vols. 1-2. Istanbul: Millî Eğitim Basımevi, 1971.

Palavestra, Vlajko. "Historijska narodna predanja i toponomastika u Fojnici i okolini." Glasnik Zemaljskog muzeja u Sarajevu (Etnologija), n.s. 27/28 (1974): 101-153.

Phillips, Amanda. "Ottoman Hil'at: Between Commodity and Charisma." In Frontiers of the Ottoman Imagination. Studies in Honour of Rhoads Murphey, edited by Marios Hadjianastasis, 111-138. Leiden, Boston: Brill, 2015.

Prijatelj Pavičić, Ivana. "Priloz poznavanju sudbine slike uskrslog Krista i kralja Stjepana Tomaša porijeklom iz Kraljeve Sutjeske.” In Stoljeća Kraljeve Sutjeske, edited by Marko Karamatić, 105-139. Kraljeva Sutjeska - Sarajevo: Franjevački samostan Kraljeva Sutjeska - Kulturno-povijesni institut Bosne Srebrene, 2010.

Quataert, Donald. "Clothing Laws, State, and Society in the Ottoman Empire, 1720-1829." International Journal of Middle Eastern Studies 29 (1997): 403-425.

Rakić, Zoran. "Svakodnevni život slikara 16. i 17. veka i svakodnevica u njihovim delima." In Privatni život u srpskim zemljama u osvit modernog doba, edited by Aleksandar Fotić, 400-431. Beograd: Clio, 2005.

Refik, Ahmet. Onuncu Asr-ı Hicrî'de İstanbul Hayatı (On Altıncı Asırda İstanbul Hayatı (1553-1591). Istanbul: Enderun Kitabevi, 1988.

Reindl-Kiel, Hedda. "Audiences, Banquets, Garments and Kisses. Encounters with the Ottoman Sultan in the 17th Century." In The Ceremonial of Audience. Transcultural Approaches, edited by Eva Orthmann and Anna Kollatz, 169-207. Göttingen: Bonn University Press, 2019.

[Šabanović, Hazim]. "Turski dokumetni u Bosni iz druge polovine XV stoljeća.” Istorisko-pravni zbornik 2 (1949): 177-208.

Šain, Mario. “'Turska pravda' - osmansko pravo u izvorima Franjevačke provincije Bosne Srebrene u 18. st." MA thesis. Faculty of Humanities and Social Sciences, University of Zagreb, 2017.

Skarić, Vladimir. "Jedna naredba o rajinom odijelu iz doba otomanske vladavine." Glasnik Zemaljskog muzeja u Sarajevu 14 (1902): 557-559. 
Stražemanac, Ivan. Povijest Franjevačke provincije Bosne Srebrene 1730. Translated by Stjepan Sršan. Osijek: Pax et bonum, 2010.

Svedružić Šeparović, Ivana. "Komplet liturgijskog ruha iz franjevačkog samostana u Zaostrogu." In VI. Zbornik Dana Cvita Fiskovića, 116-126. Zagreb: FF Press, 2016.

Szabó, János B., and Péter Erdősi. "Ceremonies Marking the Transfer of Power in the Principality of Transylvania in East European Context." Majestas 11 (2003): 111-60.

Ursinus, Michael. "Ferman sultana Bajazida II. iz 1483. i fojnička ahdnama (izdana u Milodražu).” Bosna franciscana 27, no. 51 (2019): 9-26.

Vrgoč, Miro. “Fra Anđeo Zvizdović (1420./?/-1498.).” In Duhovni stupovi Bosne Srebrene, 7-40. Sarajevo - Zagreb: Svjetlo riječi, 2007.

Vryzidis, Nikolaos. "Textiles and Ceremonial of the Greek Orthodox Church under the Ottomans: New Evidence on Hil'ats, Kaftans, Covers, and Hangings." Journal of the Ottoman and Turkish Studies Association 6, 1 (2019): 61-80.

XVIII. Yüzynl Günlük Hayatına Dair Saraybosnalı Molla Mustafảnın Mecmuası. Edited by Kerima Filan. Sarajevo: Connectum, 2011.

Zilfi, Madeline C.. "Women, Minorities and the Changing Politics of Dress in the Ottoman Empire, 1650-1830,." In The Right to Dress. Sumptuary Laws in a Global Perspective, c. 1200-1800, edited by Giorgio Riello and Ulinka Rublack, 393-425. New York, Cambridge University Press, 2019. 


\section{APPENDICES}

\section{APPENDIX 1}

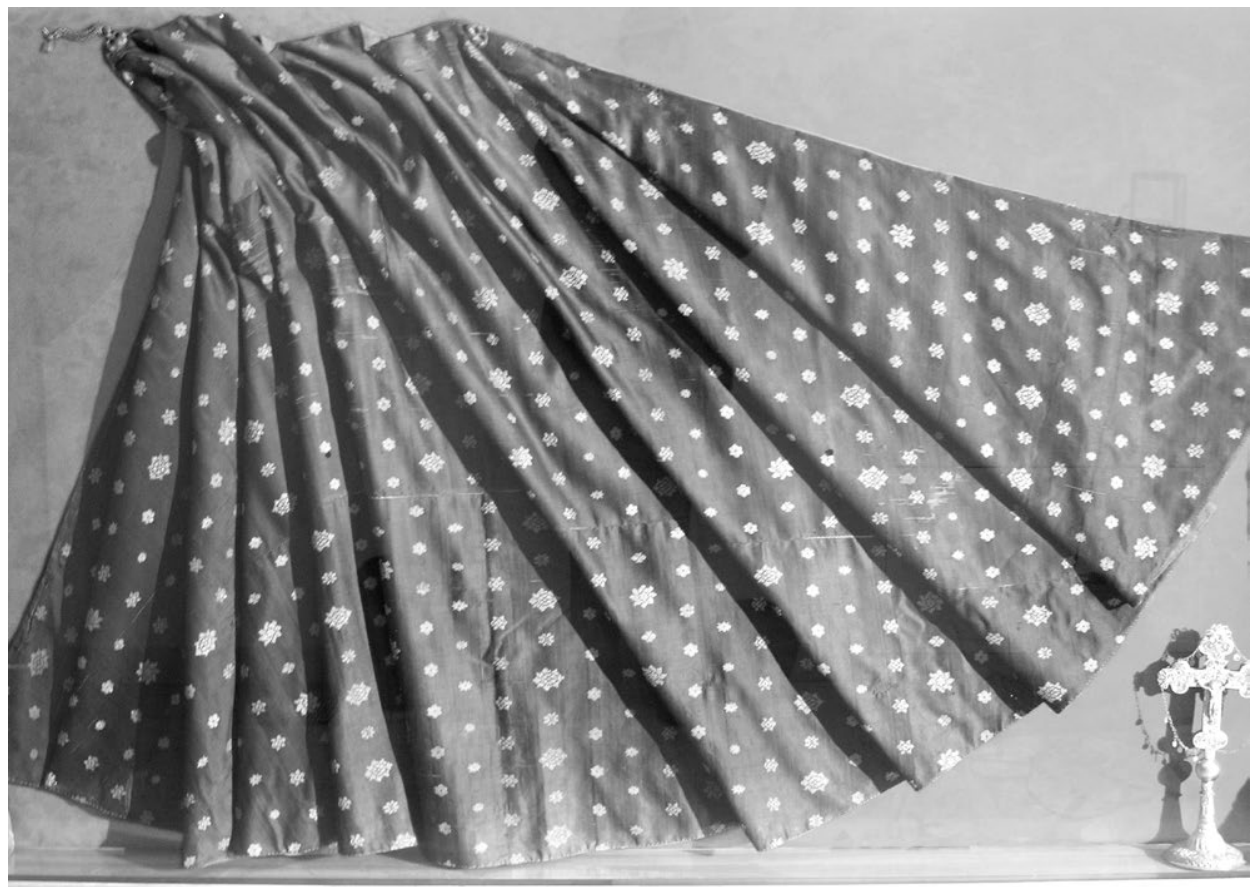

Kaftân-cloak given to the head of Bosnian Franciscans Fr. Andeo Zvizdović by Sultan Mehmed II after the conquest of Bosnia (1463)

Museum of the Franciscan Monastery of Holy Spirit, Fojnica, Bosnia and Herzegovina Photo by Vjeran Kursar (2009) 


\section{APPENDIX 2}

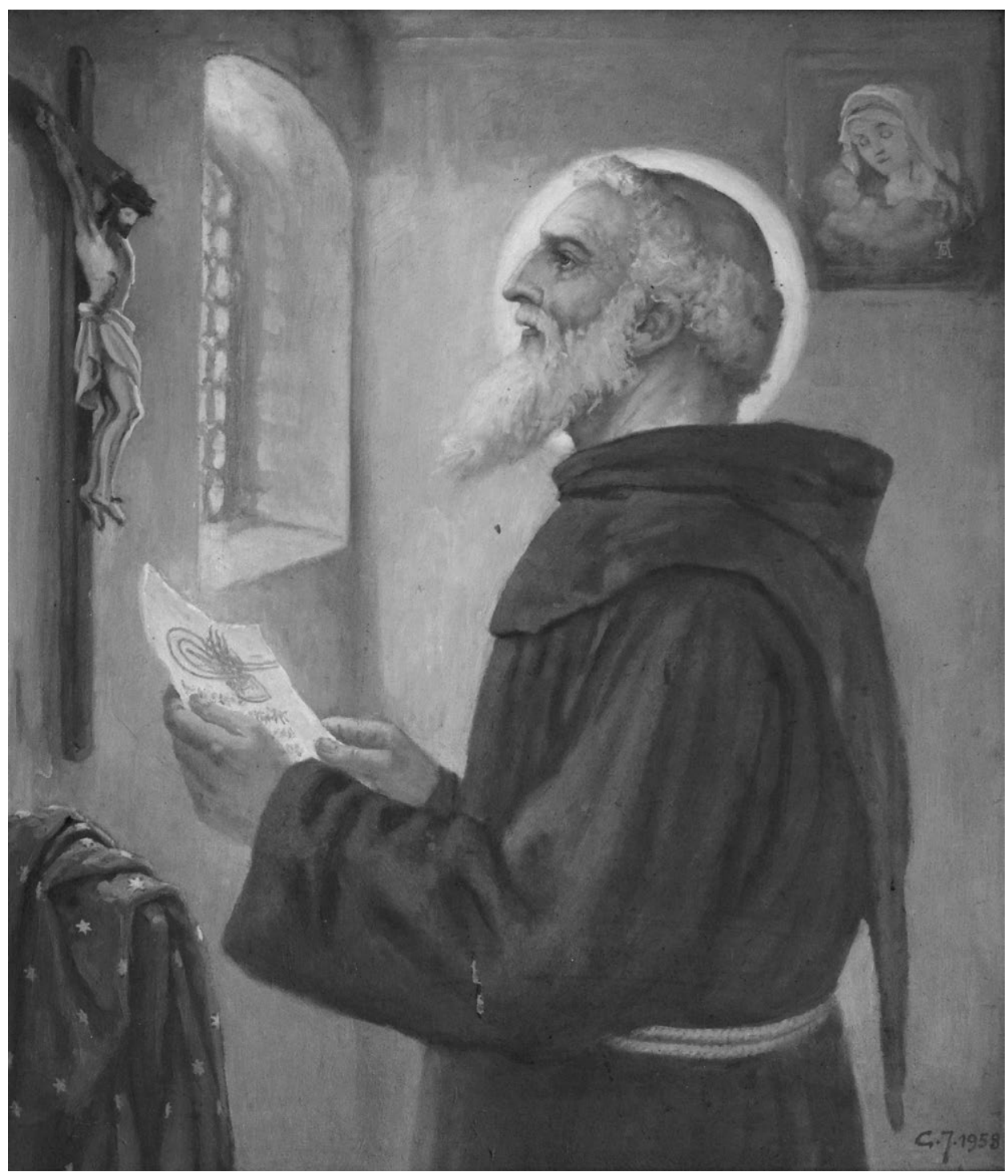

Gabrijel Jurkić: Fr. Andeo Zvizdović with ahdname and kaftan (1958) Franciscan Monastery of Holy Spirit, Fojnica, Bosnia and Herzegovina Photo by Vjeran Kursar (2014) 


\section{APPENDIX 3}

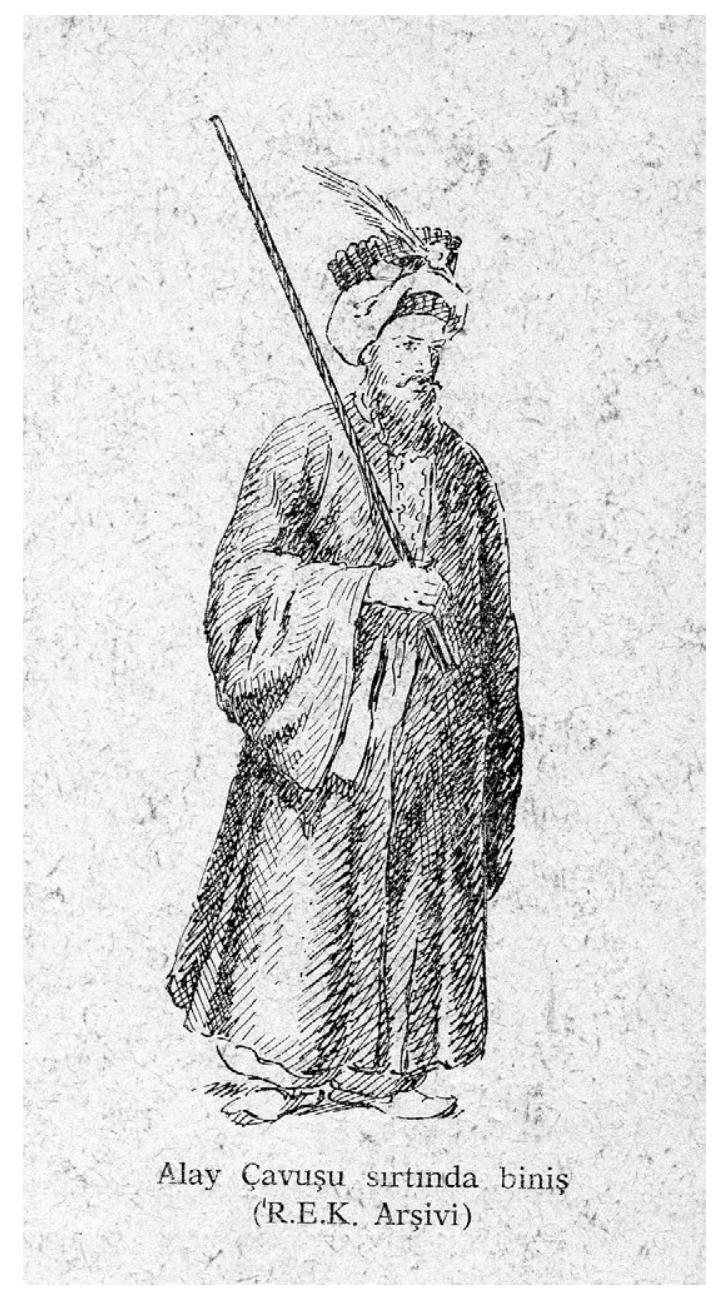

Ottoman official Alay Çavuşu wearing biniş (binjiš), a ceremonial cloak given to the representatives of the Bosnian Franciscans on several occasions in the 18th century

Source: Reşat Ekrem Koçu, Türk Giyim Kuşam ve Süslenme Sözlüğ̈̈ (Ankara: Sümerbank Kültür Yayınları, 1969), 39. 